research. The calculation is that the total value of research at Lausanne in 1987 was SFr124.4 million, of which SFr47 million came from external sources and the remainder from the regular budget.

Lausanne has also in its short lifespan accumulated a group of extra-departmental functions that occupy a third of the total staff on site, and which range from the plasma physics laboratory (page 328 ) to a land management group. A year ago, it was boasting of having become one of the centres in the international network of a dozen institutions collaborating on the numerical solution of problems in fluid mechanics. The polytechnic, the proud possessor of Cray and Cyber supercomputers, is also expected to provide supercomputer facilities for other Swiss universities, but manages itself to use 38 per cent of the available computer-time.

In the circumstances, it is odd that the polytechnic seems to have shared the general Swiss failing to appreciate the importance of the computer revolution. That this is so is nevertheless openly acknowledged. The student course in informatique was begun in 1981, and is already the third most popular.

Implicitly, this is a criticism of the system of management of the two institutions at Lausanne and Zurich, although the general opinion is that Swiss polytechnics would have awakened sooner to the need for trained computer people if Swiss industry had been quicker off the mark. "Maybe we were too slow", says Dr G. A. Grin, special adviser to the Council for the Federal Polytechnics.

Meanwhile, Grin acknowledges a different need for change. With the customary deliberation of the Swiss legislative process, proposals for reform of the council are already being canvassed. Originally intended as a means by which the confederation could support two universities without amending the constitution, the council has formally to approve the creation of new posts and even individual appointments to existing senior posts. New courses have also to be approved by the council. Similarly, sitting as it does directly on the confederation's organizational chart, the council must enforce the usual civil service rule that money unspent in one financial year should not be rolled over to the next.

On the face of things, all this suggests that the Swiss polytechnics, and that at Lausanne in particular, are but devices for bending academics' interests to the needs of industry. That they (and their institutes) perform such services is not in doubt, but there is also evident respect for the doctrine of "freedom in teaching and research" repeated in all legislation on the subject, not least in the research law of 1984. If Lausanne were better known, there would be many governments seeking to imitate it.

J.M.

Friedrich Miescher Institute

\title{
Plans for rejuvenation
}

JusT one hundred years after Friedrich Miescher discovered nucleic acids in Basle in 1869, the two independent pharmaceutical producers CIBA and Geigy agreed to found a basic research institute named after him. Although the research at the Friedrich Miescher Institute (FMI) has not quite lived up to that of Miescher himself, FMI has played a large role in training Switzerland's next generation of biologists.

FMI is strongest in plant sciences. Molecular biologists Barbara and Thomas Hohn started to work on plants when they joined FMI in the late 1970s. They had achieved distinction in discovering that bacteriophage lambda DNA is packaged into preformed virus heads, a discovery which led to the development of 'cosmids' by Barbara Hohn and John Collins. Barbara Hohn has shifted her focus to genetic flux in plants; her husband Thomas has worked lately on molecular plant virology using cauliflower mosaic virus. Fred Meins is known for his studies of cell commitment in plants.

New director Max Burger wants to rejuvenate and 'focus' FMI. A Swiss national, Burger comes to the job with 12 years of experience in the United States and 15 years at the Basle Biozentrum. His own work is in cell-cell interactions and cancer. He sees his main tasks as re-establishing neurobiology at FMI and hiring young people in areas he considers "top-

heavy". Burger would like to increase the number of "junior groups" from 20 to 40 per cent of the total.

Another task Burger has set himself is making relations with the university even better. There are more than 50 doctoral candidates at FMI and a couple of dozen more students at earlier stages - far more than at, say, the Basle Institute of Immunlogy. The students, most of whom are Swiss nationals come into contact with postdoctoral fellows from a wide variety of countries. The group leaders are quite international, too - just 5 out of 22 are Swiss.

If there is a 'sword of Damocles' hanging over FMI, it is the spectre of immigration restrictions. So far, explains Thomas Hohn, himself an Austrian, this has been a problem only in the area of student visas, where abuse of the privilege has led to tighter controls. But xenophobia in Basle would not come as a great surprise; the foreign population has risen to around 30 per cent (the average in Switzerland is 15 per cent).

Scientific relations between FMI and the now unified Ciba-Geigy are good but "could always be better" on both sides, says Burger.

However, the "burning issue" is the location of the institute. Despite the company's assurances that a new building can be found, FMI continues to be located inside the security gates of Ciba-Geigy. S.D.

\section{Industry/university cooperation}

\section{Room for further improvement}

EVEN in Switzerland, researchers express discontent from time to time. Despite the appearance of being a paradise for researchers, with solid funding, little grant-writing and openness to foreign researchers, Switzerland does not necessarily seem so idyllic to its inhabitants. "Not as nice as Singapore" cautions one biologist; "no room for Swiss researchers returning from abroad" whisper others; "times were tougher eight years ago; who knows about the future?" admonish funding-war veterans.

But, perhaps significantly, nobody denies the benefits of industry support for basic research. The Swiss chemical industry has poured millions into university research with no strings attached and universities and industry alike have reaped the rewards.

The organic chemistry department at ETH in Zurich shines brightest in this regard $(\mathrm{ETH}$, the Federal Institute of Technology, page 332). ETH professor Tadeus Reichstein performed the first chemical synthesis of vitamin C in 1933 with the help of industrial funds, a procedure that was scaled up by HoffmannLa Roche and brought the company tremendous profits.

1939 Nobel laureate Leopold Ruzicka had support from Ciba and other companies when he did his prize-winning work on isoprenes in the early part of the century. Present-day ETH chemistry professors continue to draw support for their widely respected work from the Basel chemical industry.

Former department chairman Oskar Jeger explains that success was not a requirement to receive support. "Industry"s interest was in supporting the best possible education to provide itself with manpower. It was always extremely liberal, with no strings at all." The Basle chemical companies - Hoffmann-La Roche, Ciba-Geigy and Sandoz - continue to support research in chemistry, not only at ETH but also at other universities. Ciba-Geigy, for example, supports 300 400 graduate students, half in chemistry and the rest in economics, social sciences, 